\title{
Grillotia borealis sp. n. (Cestoda: Trypanorhyncha) from five species of Bathyraja (Rajiformes: Arhynchobatidae) in the North Pacific Ocean with comments on parasite enteric distribution
}

\author{
Devon B. Keeney and Ronald A. Campbell
}

Department of Biology, University of Massachusetts-Dartmouth, 285 Old Westport Rd., North Dartmouth, Massachusetts $02747-$ 2300, USA

Key words: Cestoda, Trypanorhyncha, parasites, Grillotia, Bathyraja, zoogeography, skates, mucosal morphology

\begin{abstract}
A new trypanorhynch cestode, Grillotia borealis sp. n., is described from the spiral intestines of softnose skates of the genus Bathyraja collected from subarctic waters of the North Pacific Ocean: B. parmifera (Bean) (type host), B. aleutica (Gilbert) and B. interrupta (Gill et Townsend) from the Bering Sea and B. minispinosa Ishiyama et Ishihara and B. smirnovi (Soldatov et Pavlenko) from the Sea of Okhotsk off Japan. The new species is distinguished from other species of Grillotia by possession of the following combination of characters: four hooks per principal row, hooks 4(4') distinctly separated from hooks $3\left(3^{\prime}\right)$ of principal row, principal rows separated by 13-15 intercalary hooks in 2-3 rows, hooks 2(2') and 3(3') change in form along their respective files, hooks $1\left(1^{\prime}\right)$ do not change in form along the file, a broad band of microhooks on the external tentacular face, intermediary hooks are lacking, absence of a special basal armature, origin of the retractor muscle near middle of the bulb, average scolex ratio of $1: 3: 2: 0.1$, and a hermaphroditic sac. Grillotia borealis consistently favoured the most anterior regions of the spiral intestine. Seventy-one per cent of 21 attached worms occupied the most anterior chamber of the spiral valve and 52 per cent were embedded in the anterior surface of the spiral valve whorls. Factors which may limit the distribution of $G$. borealis within the spiral intestine of its host are discussed. Statistically significant differences occur in the mucosal morphology of B. aleutica and B. parmifera for villus length, diameter, spatial arrangement and number per unit area along the antero-posterior axis of the spiral intestine.
\end{abstract}

The genus Grillotia Guiart, 1927 consists of cestodes of the order Trypanorhyncha that possess, on the basis of the type species, Grillotia erinaceus (van Beneden, 1858), two bothridia, an atypical heteroacanthous armature with a band of microhooks, postovarian testes, prebulbar organs and bulbs usually longer than the pars bothridialis (Campbell and Beveridge 1994). Currently, 20 species of Grillotia are recognised, eight of which possess four hooks per principal row (Sakanari 1989, Campbell and Beveridge 1993, 1994, Scholz et al. 1993, Palm 1995, Beveridge and Campbell 1998). The genus is cosmopolitan in its distribution and has been recorded from a wide variety of elasmobranch hosts. However, only one species, Grillotia musculara Hart, 1936 from Raja rhina in Puget Sound, has been recorded from a skate in the North Pacific, and only a single species, Grillotia rowei Campbell, 1977, has been reported from a softnose skate belonging to the zoogeographically widespread genus Bathyraja Ishiyama (see Campbell 1977). In this paper, a new species of Grillotia is described from the softnose skates Bathyraja aleutica (Gilbert), B. interrupta (Gill et Townsend) and $B$. parmifera (Bean) taken in the Bering Sea off Alaska and $B$. minispinosa Ishiyama et Ishihara and $B$. smirnovi (Soldatov et Pavlenko) taken from the Sea of Okhotsk, north of Japan. The distribution of the new species within the host's spiral intestine is also discussed.

\section{MATERIALS AND METHODS}

Host specimens from the Bering Sea were collected in trawls during surveys by the National Oceanographic Atmospheric Administration (NOAA) research vessel Ocean Hope III in 1992 and during the second leg of the 1996 Eastern Bering Sea Groundfish and Crab Survey by the fishing trawler "Arcturus". Hosts were identified by Drs. W.C. Raschi of Bucknell University and K. Oliveira of the University of Maine for Bering Sea fish, and Dr. K. Nakaya and T. Kikuchi of Hokkaido University for fish taken in the Sea of Okhotsk. When collecting conditions at sea permitted, each spiral intestine was excised with the rectal gland attached, opened by a midventral incision, and immersed in fresh water to relax the cestodes prior to fixation with $10 \%$ neutral buffered formalin. Moribund specimens were removed and placed directly into fixative. Under adverse conditions at sea spiral valves were dissected and placed directly into fixative. Preserved spiral intestines were later transferred to $70 \%$ ethanol for storage. In the laboratory the preserved intestines were dissected and cestodes removed for further study. The enteric distribution of all cestodes was determined by numbering the chambers of the spiral intestine sequentially from anterior to posterior and recording the number of worms by species within each chamber. The site of attachment within each chamber was also noted (anterior side of whorl, posterior side of whorl or intestinal wall). Only cestodes found attached to the intestinal mucosa were included in distribution data. 
Whole mounts of worms were stained with Harris' haematoxylin, dehydrated in a graded ethanol series, cleared with methyl salicylate and mounted in Canada balsam. Some tentacles were dissected from the scolex and mounted on slides in glycerine for study of the tentacular armature. Serial and transverse sections of specimens were dehydrated in a graded tertiary butyl alcohol series, embedded in paraffin, cut at a thickness of $8 \mu \mathrm{m}$ with an American Optical Company 820 microtome, affixed with Haupt's adhesive, stained with Harris' haematoxylin, counterstained with eosin, cleared in xylene and mounted in Canada balsam. Sections of spiral valve mucosa from Bering Sea hosts were embedded in paraffin and sectioned in frontal and sagittal planes. Specimens prepared for scanning electron microscopy study were postfixed in $1 \%$ osmium tetroxide, dried with Peldri II (Ted Pella Inc., Redding, California), mounted on aluminium stubs with adhesive tape, coated with conductive silver paint and sputter coated with gold in a Hummer VI-A sputter coater. Specimens were examined and photographed in a JSM 820 (JEOL) scanning electron microscope.

Mounted specimens were observed using a Nikon Optiphot-2 microscope and photographs were taken using a Nikon FDX-35mm camera mounted to the microscope with a Nikon HIII darkbox. Drawings were made with the aid of a Nikon drawing tube. Measurements of cestodes were made using an ocular micrometer and are presented in micrometres unless otherwise noted. Measurements include the range followed in parentheses by the mean, standard deviation and sample size. In most measurements, length represents the distance along the antero-posterior axis of the cestodes and width represents a measurement made at right angles to length along the dextrosinistral axis. The length of cirrus sacs, genital ducts and spines were measured along the longest axes of those structures regardless of orientation. Testis number was estimated from cross-sections by multiplying the number of testes observed in frontal view by the number of layers of testes observed in depth. Hooks were measured following Dollfus (1942), anterior extension of hook base is referred to as the heel and posterior extension is referred to as the toe. Systematic classification and terminology follows Campbell and Beveridge (1994).

Statistical characterisation and comparisons of the spiral valve mucosae were obtained from samples of one adult specimen each of $B$. aleutica and $B$. parmifera. Tissue sampl0es, each approximately $1 \mathrm{~cm}$ square, were taken following arbitrary division of the spiral intestine into three separate regions, each with an equal number of chambers, designated as anterior, middle and posterior. Both sagittal and frontal sectional views of the valve mucosal surface from each area were used for measurements. An ocular grid micrometer $\left(1.3 \mathrm{~mm}^{2}\right)$ was calibrated and used to determine the number of villi per unit area for 10 samples within each of the three valve regions. Villus length $(\mathrm{n}=10$ per region), width $(\mathrm{n}=75$ per region) and distances between villi $(\mathrm{n}=75$ per region) were measured with a standard ruled $(0.01 \mathrm{~mm})$ ocular micrometer.

\section{RESULTS}

Grillotia borealis sp. n.

Figs. 1-19

Description: Measurements based upon 7 mature and 4 immature complete specimens (whole mounts, sections, glycerine mounts and SEM). Total length of immature specimens 1.2-2.2 $(1.8 \pm 0.6, \mathrm{n}=3) \mathrm{cm}$; mature specimens up to $8.1 \mathrm{~cm}$. Strobila acraspedote, hyperapolytic, surface covered with filiform microtriches approximately 2 long, forming clumps. Immature worms with 22-47 (39 $\pm 14, \mathrm{n}=3)$ segments, mature worms with approximately 67 segments. Scolex (Fig. 1) 4491-5248 (4819 $\pm 363, \mathrm{n}=4)$ long by 816-976 $(864 \pm 76, \mathrm{n}=4)$ wide; possessing two reverse cordiform bothridia (Fig. 2), $736(\mathrm{n}=2)$ wide, with posterior notch; pars bothridialis length 880-1040 (952 \pm 58 , $\mathrm{n}=6)$, width 748-976 (841 $\pm 84, \mathrm{n}=5)$, covered with short filiform microtriches interspersed with flattened 7-digit pectinate microtriches (Fig. 14) approximately 2 long; pars vaginalis length 2592-3344 (2874 \pm 315 , $\mathrm{n}=6)$, width 631-896 (785 $\pm 101, \mathrm{n}=6)$; pars bulbosa length 1664-1856 (1720 $\pm 69, \mathrm{n}=6)$, width 720-928 $(832 \pm 81, \mathrm{n}=6)$, covered with short filiform microtriches (Fig. 15) approximately 1 long; pars postbulbosa length 91-208 (151 $\pm 49, \mathrm{n}=5)$, width 761-880 (811 \pm $50, \mathrm{n}=5)$; scolex ratio (pb : pv : pbulb : ppb) $1.0: 2.7:$ $1.6: 0.1$ to $1.0: 3.6: 1.9: 0.2$. Bulbs approximately 8.5 times longer than wide, length 1664-1856 (1720 \pm 69 , $\mathrm{n}=6)$; width 169-228 (203 $\pm 20, \mathrm{n}=6)$; tentacle sheaths form prebulbar swelling, 83-112 $(101 \pm 8, \mathrm{n}=6)$ by 99 $118(103 \pm 7, \mathrm{n}=6)$. Tentacle sheaths sinuous, width 98-111 $(105 \pm 9, \mathrm{n}=2)$; origin of retractor muscle slightly anterior to middle of bulb (Fig. 3). Tentacles (Fig. 7) long and tapered, length 2217-2457 (2333 \pm $121, \mathrm{n}=4)$, tip diameter 20-33 (24 $\pm 8, \mathrm{n}=3)$, approximately 99 wide at base. Armature heteroacanthous atypical, hooks heteromorphous, hollow, basal armature absent (Fig. 10), metabasal armature (Figs. 9, 16) with a band of microhooks (Figs. 8, 18) on external surface. Principal hook rows forming alternating half-spirals of 4 large hooks with displacement of hook 4(4'), rows begin on internal face and end on external face (Figs. 14, 17). Principal rows separated by 13-15 intercalary hooks in 2-3 rows (Figs. 9, 17). Intercalary rows begin posterior to space between hooks 2(2') and 3(3') and merge with band on external surface (Figs. 8, 16-18). Hooks 1(1') uncinate, length 55-57, base 35-47, height 16-29, heel 9-10, toe 11-20, decreasing in length in distal portions of files. Hooks 2(2') uncinate in basal and proximal metabasal region and falciform with recurved tip in distal metabasal region (Figs. 11, 13, 19), length 45-57, base 19-24, height 30-35, heel 3-5, toe 1 . Hooks 3(3') uncinate, changing shape to spiniform with a transverse base at rows 13 or 14 (Figs. 7, 11,13 ); length $29-44$, base $17-33$, height $17-21$, heel 612 , toe 1-8. Hooks 4(4') spiniform, tip notched (Figs. $11,14,17$ ); hook length 45 , base length 10 , height 13 , 
1

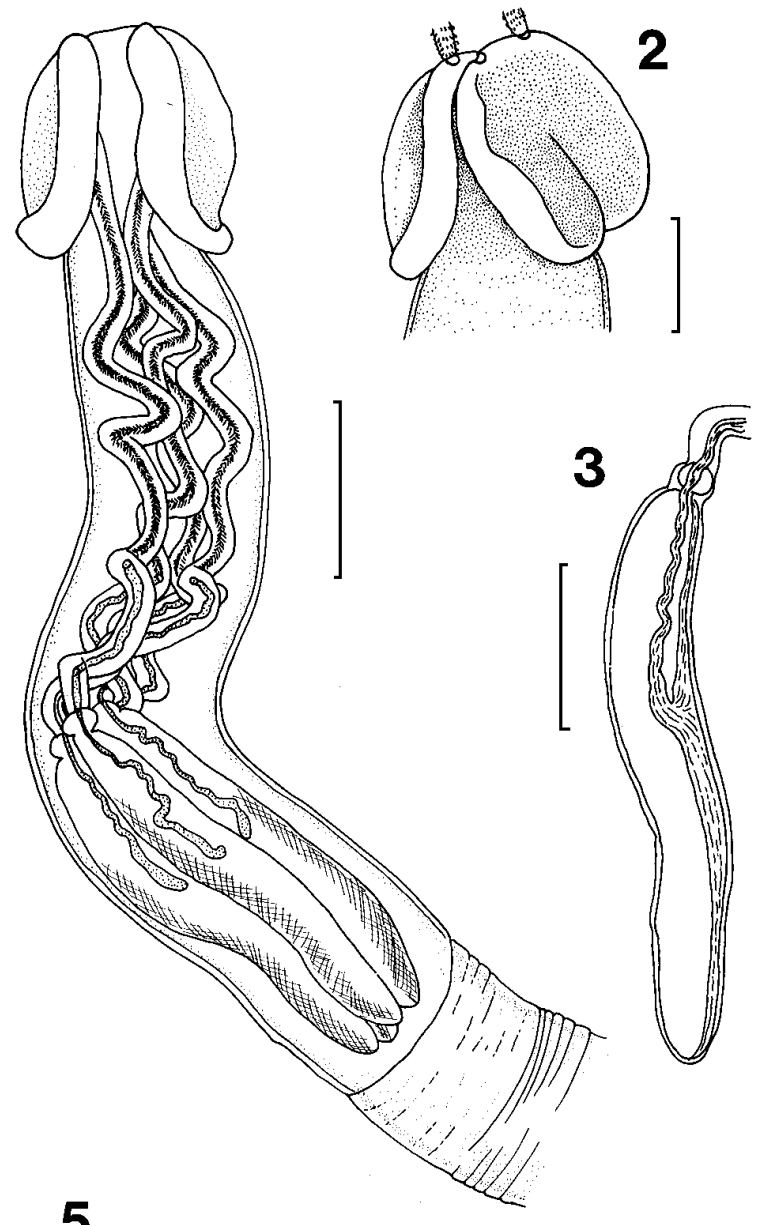

\section{4}

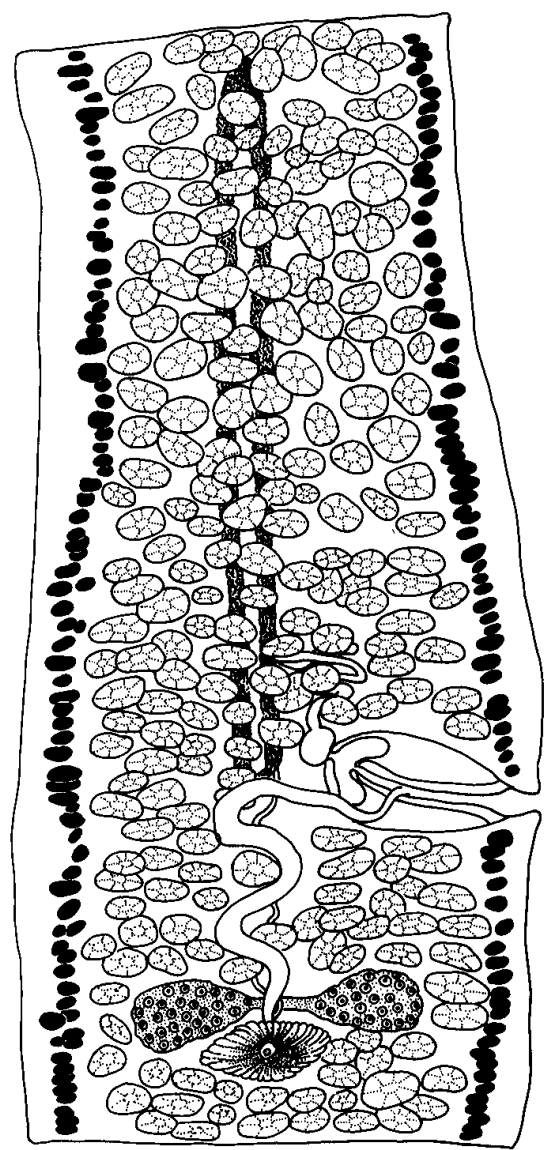

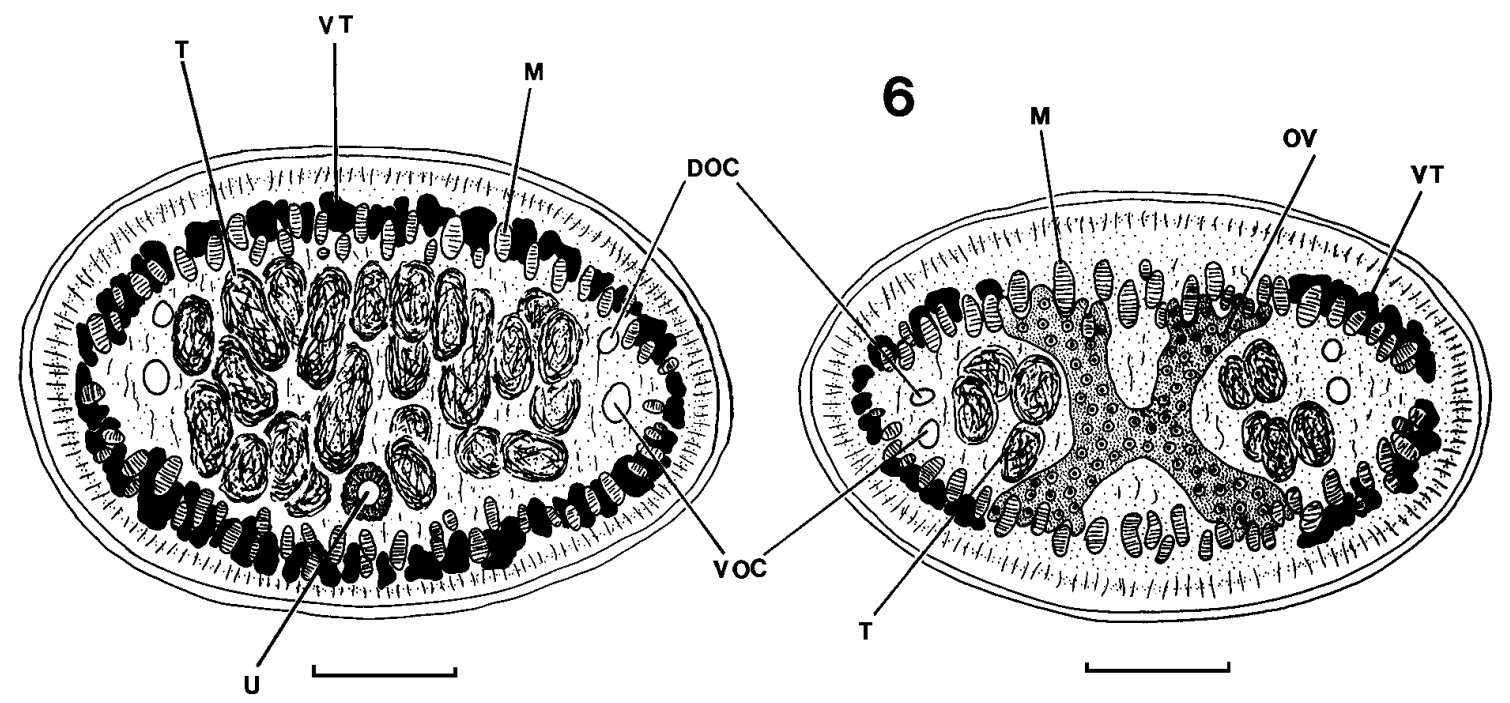

Figs. 1-6. Grillotia borealis sp. n. Fig. 1. Scolex. Fig. 2. Pars bothridialis. Fig. 3. Bulb. Fig. 4. Mature segment, vitelline follicles only shown on lateral margins for clarity. Fig. 5. Mature segment, cross-section anterior to genital pore. Fig. 6. Mature segment, cross-section through ovary. Abbreviations: DOC - dorsal osmoregulatory canal; $\mathrm{M}$ - longitudinal muscle; OV - ovary; T testis; U - uterus; VOC - ventral osmoregulatory canal; VT - vitelline follicle. Scale bars: Fig. $1=700 \mu \mathrm{m}$; Figs. $2,3=50 \mu \mathrm{m}$; Fig. $4=300 \mu \mathrm{m}$; Figs. 5, $6=200 \mu \mathrm{m}$. 
heel and toe length 1. Longitudinal band of 6-8 files of microhooks separates principal rows on external face (Figs. 8, 18). Immature segments approximately 40 in number, $26-528(277 \pm 355, \mathrm{n}=2)$ long by $512-689$ $(601 \pm 125, \mathrm{n}=2)$ wide. Mature segments (Fig. 4) approximately 27 in number, 429-1840 (1291 \pm 705 , $\mathrm{n}=5)$ long by 560-896 (772 $\pm 145, \mathrm{n}=6)$ wide. Segments encircled by row of approximately 53-60 longitudinal muscle bundles. Testes numerous, c. 500 per segment, distributed in prevaginal, postvaginal, aporal and postovarian intervascular fields, subspherical, 38-54 $(44 \pm 4, \mathrm{n}=20)$ long by 45-86 $(69 \pm 12$, $\mathrm{n}=25)$ wide by $67-112(88 \pm 18, \mathrm{n}=5)$ deep. Genital pore lateral, in posterior $27-38(31 \pm 4, n=5) \%$ of mature segments, posterior $52 \%$ of terminal segment. Hermaphroditic sac pyriform, approximately 461 long by 192 wide, traversing about $35-40 \%$ of segment width. Vas deferens medial, coiled slightly anterior to genital pore descending to form external seminal vesicle connected to anterior, medial portion of hermaphroditic sac; sperm duct enters medial pole of sac and forms internal seminal vesicle. Vagina runs anteriorly from shell gland, turns ventrally below hermaphroditic sac and internal seminal vesicle, penetrates hermaphroditic sac and connects with male seminal duct forming hermaphroditic duct (Figs. 4, 12). Ovary in posterior $22 \%$ of segment, tetralobed, maximum dimensions approximately 189 long by 358 wide, isthmus 19-42 (31 $\pm 16, \mathrm{n}=2$ ) wide. Shell gland posterior to ovarian isthmus, subspherical, c. 100 long by 195 wide. Uterine duct extends from shell gland to level of genital pore, then enters uterus. Uterus median, tubular, 93-99 (96, $\mathrm{n}=2$ ) wide, extending from level of genital pore almost to anterior margin of segment. Vitellaria small, follicular, follicles $13-19(16 \pm 2, \mathrm{n}=6)$ long by 29-60 (48 \pm $14, \mathrm{n}=6$ ) wide, circumcortical, interspersed among longitudinal muscles. Dorsal osmoregulatory canal 26$29(28, \mathrm{n}=2)$ in diameter, ventral osmoregulatory canal 45-51 $(48, \mathrm{n}=2)$ in diameter.

$\mathrm{T}$ y $\mathrm{p}$ e $\mathrm{h}$ o $\mathrm{s}$ t : Bathyraja parmifera (Bean); Arhynchobatidae, softnose skates.

$\mathrm{S}$ i $\mathrm{t}$ e : Spiral intestine, in anterior one-third, $71 \%$ of specimens in most anterior chamber.

$\mathrm{T}$ y p e 1 o c a 1 i t y : Bering Sea $\left(61^{\circ} 00^{\prime} 53^{\prime \prime} \mathrm{N}\right.$, $173^{\circ} 26^{\prime} 91^{\prime \prime} \mathrm{W}$ ).

T у p e m a t e r i a 1 : ex Bathyraja parmifera. Spiral intestine. USNPC holotype No. 90678 with serial sections and 2 paratypes No. 90679 and 90680 and separate tentacles, No. 90681, deposited in the United States National Parasite Collection, Beltsville, Maryland, USA; 1 paratype and tentacle, No. C-336, are in the Institute of Parasitology, Academy of Sciences of the Czech Republic.

A d d it i o n a $1 \mathrm{~m}$ a t e ri a $1 \mathrm{st}$ u d i e d: Bering Sea, Bathyraja aleutica (Gilbert), 1 specimen, $\left(56^{\circ} 59^{\prime} 88^{\prime \prime} \mathrm{N}\right.$, $\left.167^{\circ} 41^{\prime} 75^{\prime \prime} \mathrm{W}\right)$; Bathyraja interrupta (Gill et Townsend), 1 specimen, (56 $\left.50^{\circ} 47^{\prime} \mathrm{N}, 170^{\circ} 28^{\prime} 59^{\prime} \mathrm{W}\right)$. Sea of Okhotsk (coordinates not available): Bathyraja minispinosa Ishiyama et Ishihara, 1 specimen; Bathyraja smirnovi (Soldatov et Pavlenko), 14 specimens.

\section{DISCUSSION}

\section{Differential diagnosis}

The description of this new species expands the host list of Grillotia to include five new hosts in the genus Bathyraja, specifically, $B$. parmifera (type host), $B$. aleutica and $B$. interrupta from the Bering Sea and $B$. minispinosa and B. smirnovi from the Sea of Okhotsk. The only previous record of Grillotia from Bathyraja is that of Campbell (1977) for an immature adult taken from $B$. richardsoni in the western North Atlantic Ocean. Grillotia borealis can be distinguished from all congeners by its combination of four hooks per principal row, hooks 4(4') widely separated from 3(3'), possession of a total of 13-15 intercalary hooks in 2-3 rows, change in shape of hooks 2(2') and 3(3') in distal regions of the hook files, lack of an intermediary hook between the principal rows, presence of a broad band of microhooks on the external tentacular surface, and relatively long bulbs with origin of the retractor muscle in the middle of the bulb. Currently, eight species of Grillotia are known which possess 4 principal hooks per row and are sufficiently well described to be considered valid. $G$. borealis can be differentiated from all of these species in having the origin of the retractor muscle in the middle of the bulb. Furthermore, G. bothridiopunctata Dollfus, 1969 can be differentiated by its long, thin, falciform principal hooks, small hook bases, 2-3 intercalary hooks per row and special basal armature with falciform hooks. The retractor muscle of $G$. smarisgora (Wagener, 1854) has an anterior origin of the retractor muscle, its bulbs are short and it possesses a basal armature and only a single intercalary row of 4-5 hooks between principal rows of the metabasal armature. G. angeli Dollfus, 1969 differs in possessing a basal armature with falciform hooks, a single intercalary row of 1 or 2 hooks and basal origin of the retractor muscle. Only five species share with $G$. borealis the combination of separation of hooks $4\left(4^{\prime}\right)$ in the principal row, possession of 2-3 intercalary rows and absence of a special basal armature; they are: G. dollfusi, $G$. erinaceus (van Beneden, 1858), G. musculara (Hart, 1836), G. pseudoerinaceus Dollfus, 1969 and $G$. recurvispinis Dollfus, 1969. All of these species resemble $G$. borealis in lacking falciform or bill-hooks on the base but differ in having a basal origin of the retractor muscle. The presence of a hermaphroditic sac in $G$. borealis is unknown in other species of Grillotia and possibly distinctive. The scolex ratio of $G$. dollfusi is $1: 2: 1.5$ vs. $1: 3: 2$ for $G$. borealis, bases of hooks 3(3') of $G$. dollfusi are T-shaped but change in form at rows 13-14 in G. borealis and hooks 2(2') of G. dollfusi maintain a consistent shape whereas those of $G$. borealis change in form. Furthermore, upon examina- 

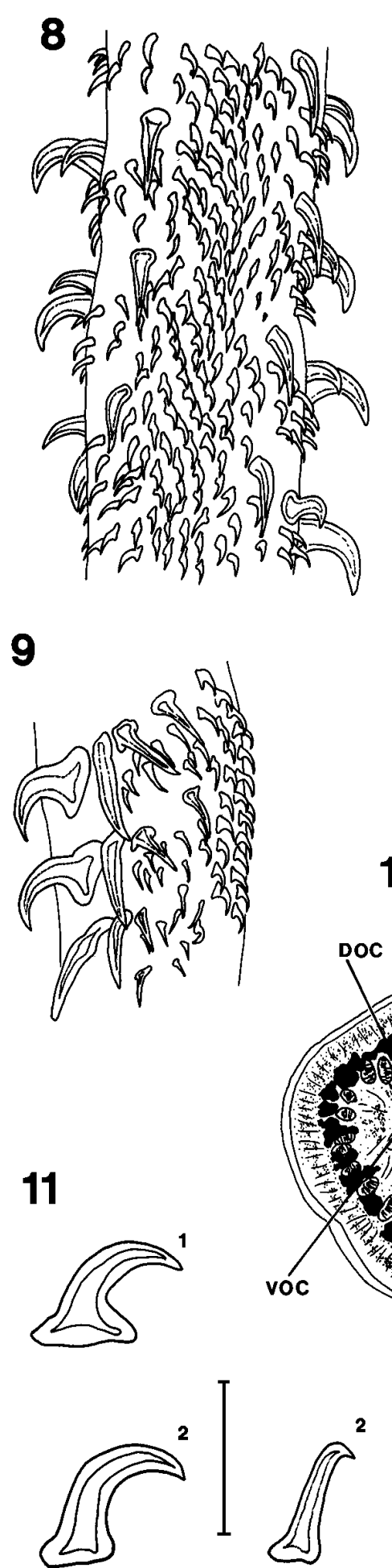

\section{2}

10

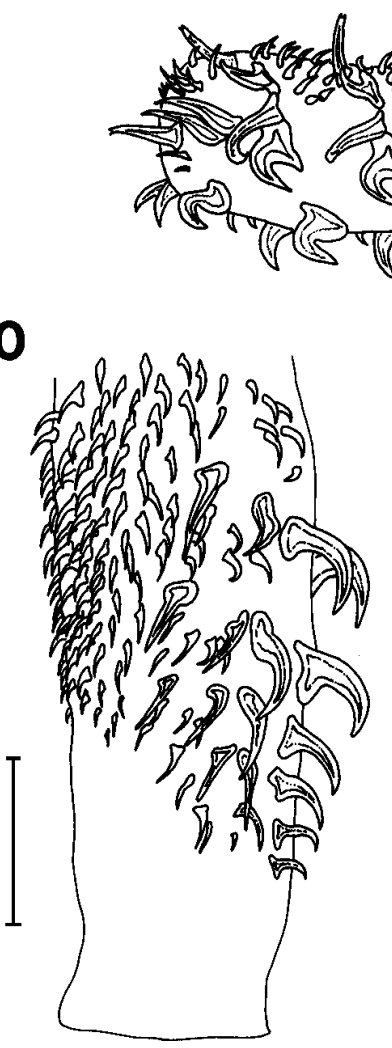

12
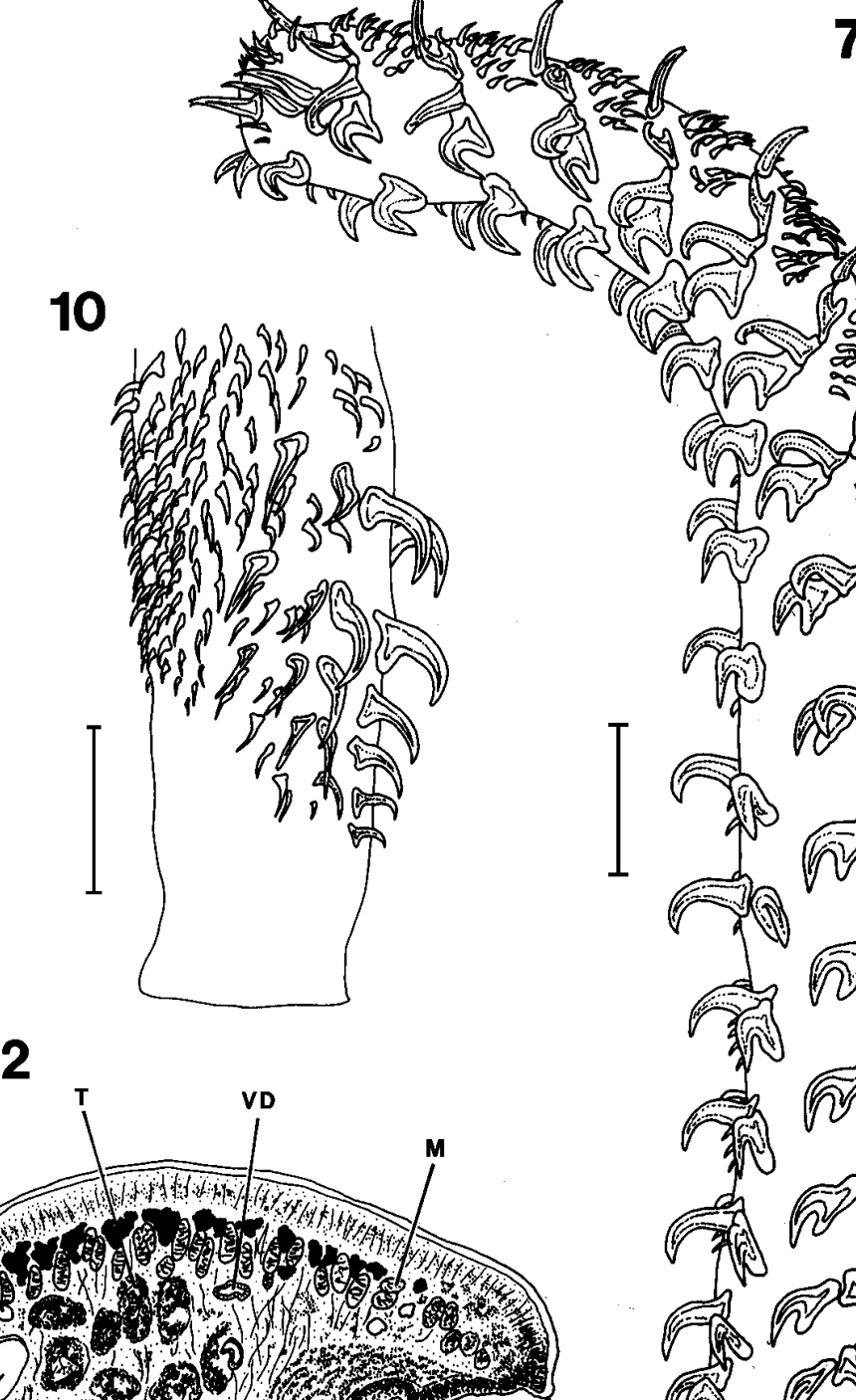

7
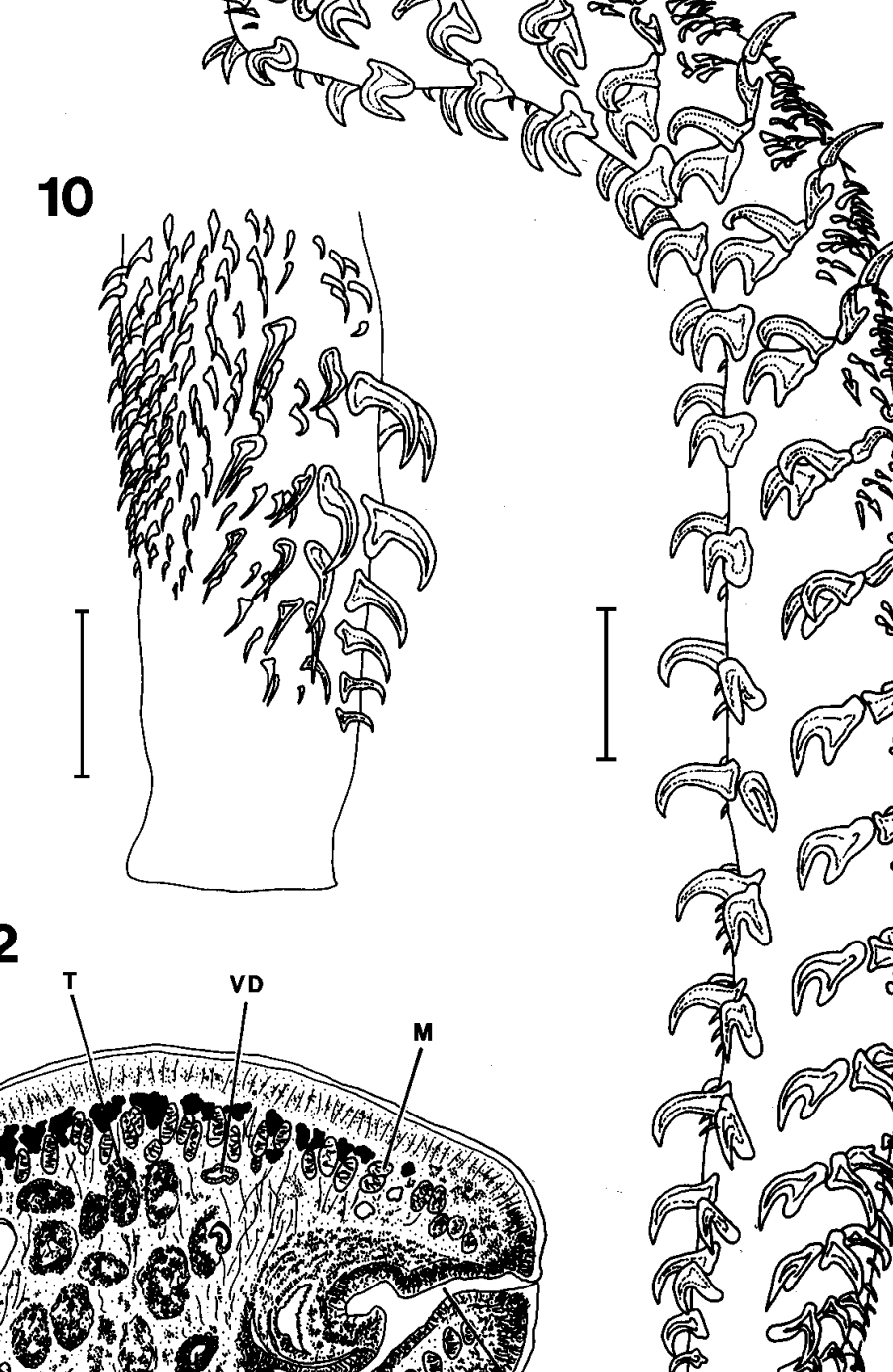

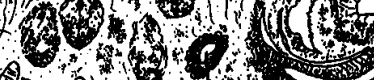
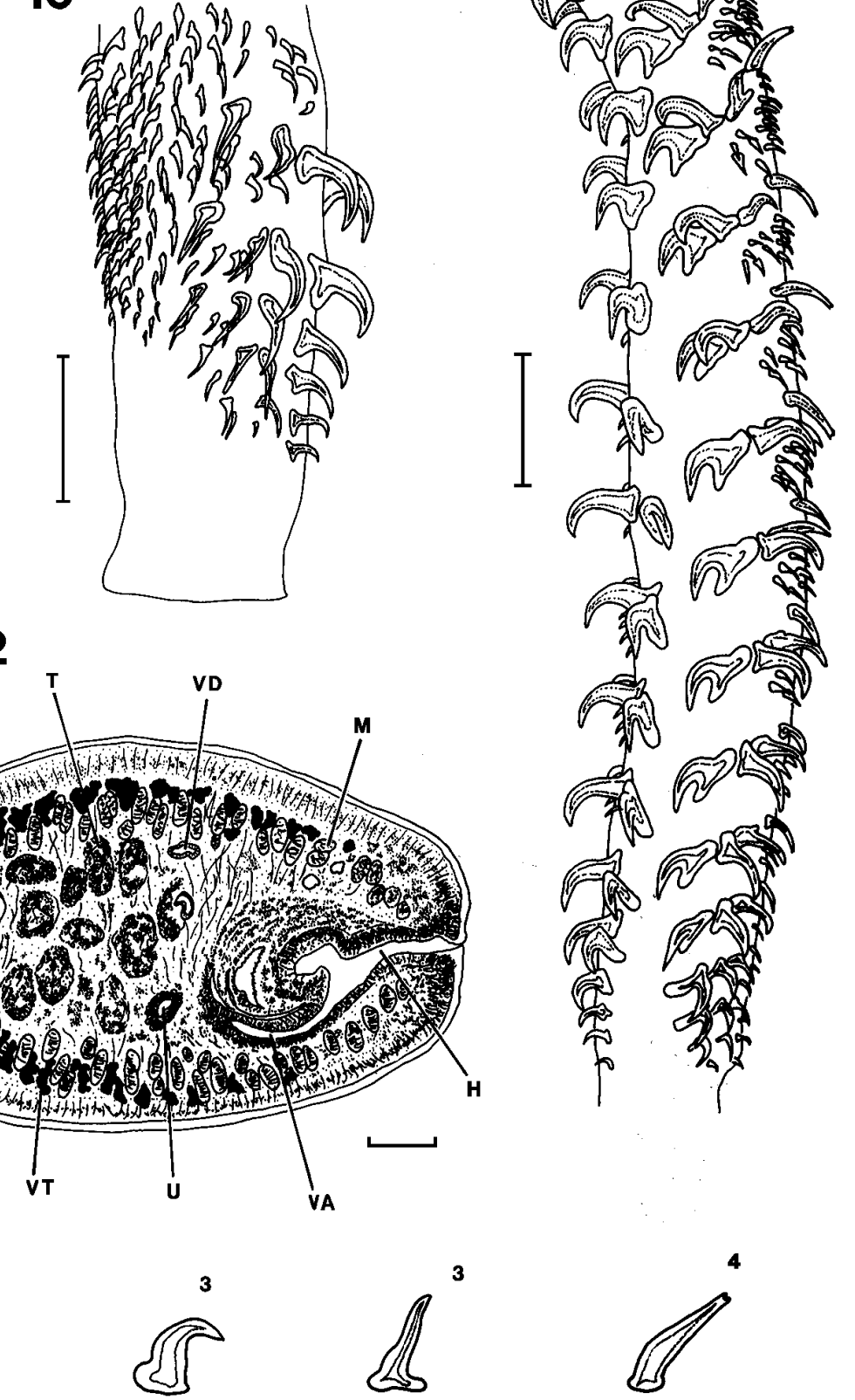

Figs. 7-12. Grillotia borealis sp. n. Fig. 7. Tentacle, internal surface at left. Fig. 8. Band of microhooks on external surface of metabasal region of tentacle. Fig. 9. Metabasal armature, bothridial surface. Fig. 10. Basal armature, bothridial surface; internal surface at right. Fig. 11. Profiles of principal hook, note change in form of hooks 2(2') and 3(3'). Fig. 12. Cross-section through hermaphroditic sac, note junction of vagina with male duct in hermaphroditic sac. Abbreviations: DOC - dorsal osmoregulatory canal; $\mathrm{H}$ - hermaphroditic duct; $\mathrm{M}$ - longitudinal muscle; OV - ovary; T - testis; U - uterus; VA - vagina; VD - vas deferens; VOC - ventral osmoregulatory canal; VT - vitelline follicle. Scale bars: Fig. $7=100 \mu \mathrm{m}$; Figs. 8-10 = $500 \mu \mathrm{m}$; Fig. $11=50 \mu \mathrm{m}$; Fig. $12=20 \mu \mathrm{m}$. 
tion of the type specimens, it is noted that the bulbs of $G$. dollfusi appear to have a bulb within a bulb, Pintner's cells are present and the cavity of hooks 1(1') extends into the heel. Grillotia erinaceus, G. musculara, G. pseudoerinaceus and $G$. recurvispinis all differ from $G$. borealis in the form of principal hooks 2(2')-4(4') and in possession of a basal origin of the retractor muscle. In G. erinaceus principal hooks 2(2') and 3(3') do not change in form along the files as in G. borealis and an accessory seminal vesicle is present (Beveridge I., Univ. Melbourne, Australia; pers. comm.) which is lacking in G. borealis. G. musculara possesses a small intermediary hook between primary hooks 1, (1') and 2, (2') which is not present in G. borealis. Grillotia pseudoerinaceus can be readily distinguished from $G$. borealis by its short bulbs, fewer intercalary hooks (7-10) and the location of hooks 3(3') anterior to 2(2') instead of being aligned in rank along the principal rows. $G$. recurvispinis differs from $G$. borealis in possessing fewer (9-10) intercalary hooks in 3-5 rows (2 rows in figs.), a dense band of microhooks that extends all the way to the base of the tentacle and large basal hooks, and hooks 2(2') and 3(3') do not undergo a change in form along the files as they do in $G$. borealis (see Dollfus 1969).

\section{Distribution}

Distribution data for $G$. borealis are based on observations of 21 attached specimens, 15 of which were mature and 6 immature. All specimens, except one, were found attached within the anterior third of the host's spiral valve and $71 \%$ of the specimens were recovered from the most anterior valve chamber. Eleven of the cestodes were recovered from the anterior side of the spiral valve whorls, three were recovered from the posterior side and the remaining seven individuals were found attached to the intestinal wall.

The enteric distribution of $G$. borealis may be affected by host intestinal morphology. Individuals of $G$. borealis were consistently found in the anterior chambers of spiral valves, where villi were longest. Length of intestinal villi decreased in all hosts along the antero-posterior axis of the valve and only one specimen of $G$. borealis was recovered posterior to the anterior third of the spiral valve. Grillotia spp. have been shown to occupy only anterior valve regions in the nurse shark where secondary crypts are apparently large enough to allow room for attachment (Borucinska and Caira 1993). Secondary crypts were present in species of Bathyraja from the Bering Sea, but were not measured. However, in both B. aleutica and B. parmifera, one-way ANOVA found significant differences in comparisons of the anterior, middle and posterior regions for villus length (both species, anterior-middle and anteriorposterior; $\mathrm{P}<0.0001$ ), distance between villi (anteriorposterior; B. aleutica $\mathrm{P}=0.0041$ and $B$. parmifera $\mathrm{P}<$ $0.0001)$ and number per $1.3 \mathrm{~mm}^{2}$ area $(B$. aleutica, anterior-middle $\mathrm{P}=0.0332$, anterior-posterior $\mathrm{P}<$
0.0001; B. parmifera, anterior-posterior $\mathrm{P}=0.0038$ ). Therefore the anterior preferences of $G$. borealis and other cestode species comprising the faunas of these hosts indicates that villus length affects cestode distribution and is the morphological attribute responsible for crypt depth and both a decrease in villus diameter (B. aleutica, antero-posterior $\mathrm{P}=0.0025$ ) and numbers of villi per unit area affect crypt width in the spiral valve mucosa in these host species.

A tighter coiling of spiral valve whorls existed posteriorly in the species of Bathyraja examined and was also observed in skates (Raja spp.) examined by Williams (1968). The most posterior chambers became closely spaced creating less room for cestodes. Grillotia borealis was one of the largest species of cestodes encountered in these hosts and its distribution may be limited, at least in part, by the amount of space available.

Williams'(1960) original hypothesis explaining the distribution of cestodes within the elasmobranch host intestine emphasised the structure of the tetraphyllidean tapeworm scolex relative to the mucosal morphology as the prime factor determining host-specificity and location within the intestine. This hypothesis by Williams (1960) was later modified by adding that the ecology of the host and physiology of the host's intestine might be more important in host-specificity and location of tetraphyllidean cestodes within the spiral valve (Williams et al. 1970). This has received support from other authors who compared cestode distribution with mucosal morphology (Williams et al. 1970, Williams 1982, Borucinska and Caira 1993, Curran and Caira 1995, Campbell - unpubl. data,). Tetraphyllidean cestodes of the genus Echeneibothrium with a large myzorhynchus and open, multi-loculated bothridia tend to be located in anterior chambers as there is typically more space between folds or villi allowing for more room for attachment (Williams 1966, 1968, Carvajal and Dailey 1975, McVicar 1979).

Despite the high consumption of protein and the tendency of older (larger) skates to eat more fish, frequently reported in the literature, several authors have proposed that a physiological gradient caused by differing rates of digestion and absorption of carbohydrates, instead of protein, affects the distributions of cestodes within the spiral intestine. The first examples being studies of cestodes of the tetraphyllidean genera Echeneibothrium and Acanthobothrium (Williams 1960, Williams et al. 1970, McVicar 1979). Monosaccharides have been demonstrated to be absorbed in anterior regions of the elasmobranch spiral intestine whereas disaccharides are absorbed posteriorly and may be the only carbohydrates available in the posterior region (Read 1957, Laurie 1961, Carlinsky and Huang 1962). A physiological gradient of some type may also influence the distribution of $G$. borealis in species of Bathyraja examined as specimens were predominantly found in the anterior chambers of the spiral valve. 

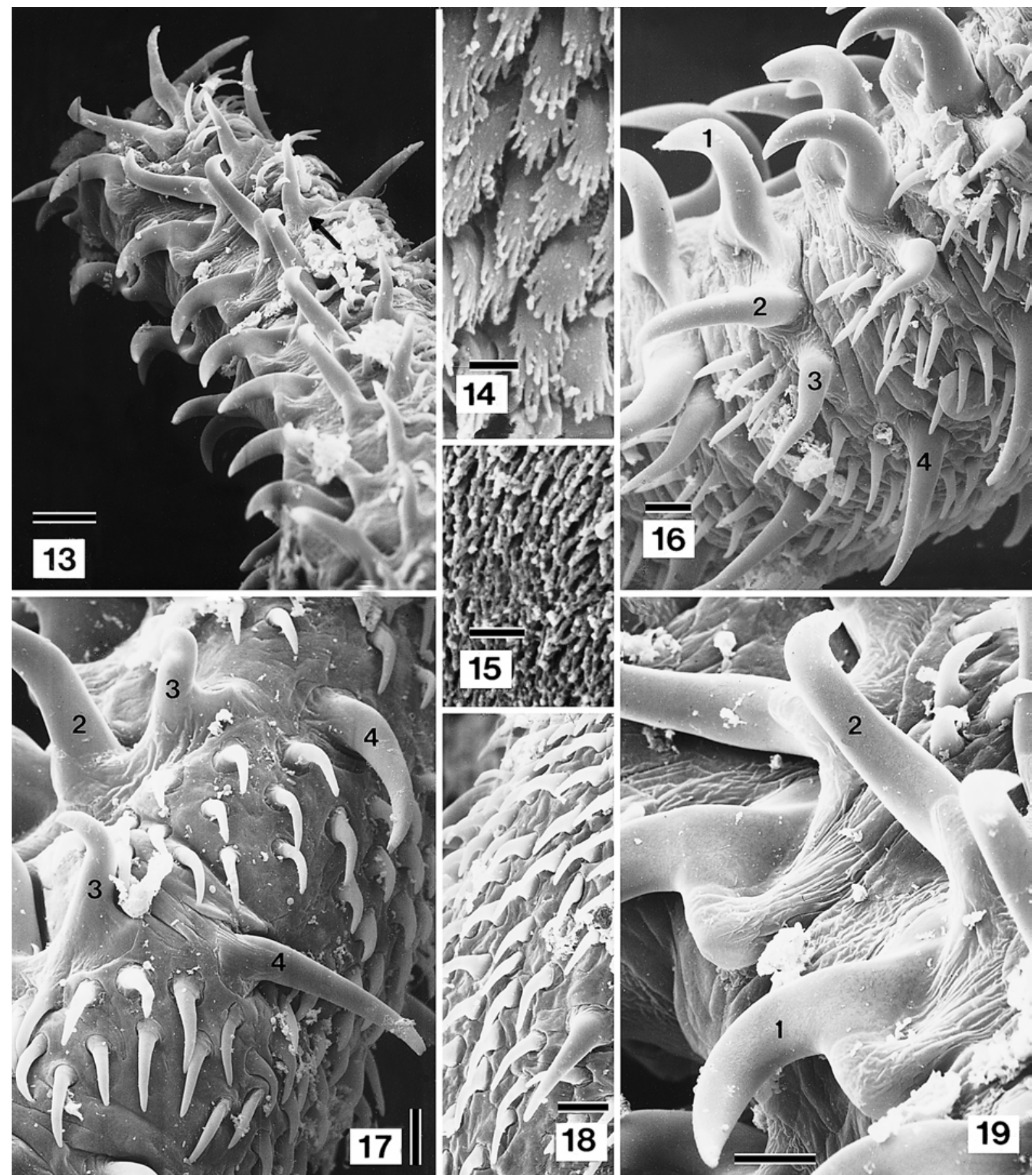

Figs. 13-19. Grillotia borealis sp. n., scanning electron micrographs. Fig. 13. Distal metabasal armature. Note crochet-hook shape of hooks 2(2'). The transverse orientation of the bases of principal hooks 3 is clearly visible (arrow). Fig. 14. Pectinate microtriches on surface of bothridium. Fig. 15. Filiform microtriches on surface of pars bulbosa. Fig. 16. Metabasal armature, bothridial surface, principal hooks numbered (1-4). Fig. 17. Metabasal armature. Note change in morphology of hooks 3, notched tips of hook 4, and intercalary rows. Fig. 18. Proximal metabasal armature. Note merging of intercalary rows with band of microhooks on external surface at left. Fig. 19. Detail of hook files 1 and 2 in upper metabasal region. Scale bars: Figs. 13, 16-19 $=10 \mu \mathrm{m}$; Figs. $14,15=1 \mu \mathrm{m}$. 
Grillotia spp. seem to prefer the anterior region of the spiral valve and are absent from the posterior region except following conditions in which the host had been starved (Campbell, unpubl. data). Cestodes of all kinds were consistently absent from the posterior chambers of the spiral valves of all species of Bering Sea hosts except for a single host from the Sea of Okhotsk in which Phyllobothrium sp. was present. Phyllobothrium spp. possess bothridia that can spread out across short villi often encountered in posterior regions of the spiral intestine and have been shown to absorb disaccharides (Laurie 1961, Williams 1968, Williams et al. 1970, McVicar 1979). The lack of cestodes in posterior regions of both helical and scroll-type valves (Garman 1913) has been reported in sharks and stingrays (Williams 1982, Cislo and Caira 1993, Curran and Caira 1995). The influence of inter- and intraspecific variation in the number of valve chambers (Daniel 1934) has not been considered. Williams (1982) made a detailed statistical comparison of the mucosal morphology and distribution of the cestode faunal assemblages in Prionace glauca, Dasyatis centroura, and Rhinoptera bonasus. Linear differences in mucosal morphology were visually and statistically apparent in $P$. glauca and $D$. centroura agreeing with the morphological explanation for the observed distributions of the cestode faunal assemblage. However, in the cownose stingray, Rhinoptera bonasus, some cestode species showed marked preferences for certain chambers within the spiral valve despite the fact that the mucosal morphology did not differ visually or statistically from other chambers. Only at the extreme posterior region of the spiral valve did the mucosa show statistically significant and visual changes rather similar to that observed in species of Bathyraja. These observations suggest that cestode faunal distributions must result from a combination of morphological and physiological characteristics of the host and parasite. However, evidence corroborating the interaction of both physiology and morphology in the distribution of the cestode faunal assemblage has yet to be carefully scrutinised for any species of the sharks and rays.

Acknowledgements. We gratefully acknowledge Dr. William Raschi of Bucknell University and Dr. Kenneth Oliveira, currently at the University of Maine, for the collection and identification of Bering Sea skates, and Dr. Kazuhiro Nakaya and especially Tomokazu Kikuchi of the Hokkaido University for the collection and identification of skates from the Sea of Okhotsk and Dr. J. Ralph Lichtenfels, Curator, U.S. National Parasite Collection, for loan of type specimens. This study was supported by the National Marine Fisheries Service, "Systematics and Natural Histories of Bering Sea Skates (No. 52ABNF100083)" to W.C. Raschi, Bucknell University, University of Massachusetts-Dartmouth Foundation Award (FRS 552605) to R.A. Campbell, and an award from the American Museum of Natural History, Lerner Gray Fund for Marine Research, to D.B. Keeney.

\section{REFERENCES}

BEVERIDGE I., CAMPBELL R.A. 1998: Re-examination of the trypanorhynch cestode collections of A.E. Shipley, J. Hornell and T. Southwell, with the erection of a new genus, Trygonicola, and redescriptions of seven species. Syst. Parasitol. 39: 1-34.

BORUCINSKA J., CAIRA J.N. 1993: A comparison of mode of attachment and histopathogenicity of four tapeworm species representing two orders infecting the spiral intestine of the nurse shark, Ginglymostoma cirratum. J. Parasitol. 79: 238-246.

CAMPBELL R.A. 1977: New tetraphyllidean and trypanorhynch cestodes from deep-sea skates in the western North Atlantic. Proc. Helminthol. Soc. Wash. 44: 191-197.

CAMPBELL R.A., BEVERIDGE I. 1993: New species of Grillotia and Pseudogrillotia (Cestoda: Trypanorhyncha) from Australian sharks and definition of the family Grillotiidae Dollfus, 1969. Trans. R. Soc. S. Aust. 117: 3746.

CAMPBELL R.A., BEVERIDGE I. 1994: Order Trypanorhyncha Diesing, 1863. In: L.F. Khalil, A. Jones and R.A. Bray (Eds.), Keys to the Cestode Parasites of Vertebrates. CAB International, Wallingford, pp. 51-148.

CARLINSKY N.J., HUANG K.C. 1962: Glucose transport by the intestinal mucosa of the dogfish. Proc. Soc. Exp. Biol. Med. 109: 405-408.

CARVAJAL J., DAILEY M.D. 1975: Three new species of Echeneibothrium (Cestoda: Tetraphyllidea) from the skate,
Raja chilensis Guichenot, 1848, with comments on mode of attachment and host specificity. J. Parasitol. 61: 89-94.

CISLO P.R., CAIRA J.N. 1993: The parasite assemblage in the spiral intestine of the shark Mustelus canis. J. Parasitol. 79: 886-899.

CURRAN S., CAIRA J.N. 1995: Attachment site specificity and the tapeworm assemblage in the spiral intestine of the blue shark (Prionace glauca). J. Parasitol. 81: 149-157.

DANIEL J.F. 1934: The Elasmobranch Fishes. University of California Press, Berkeley, California, 332 pp.

DOLLFUS R.P. 1942: Etudes critiques sur les tétrarhynques du Muséum de Paris. Arch. Mus. natl. Hist. nat., Paris, 6 sér. 19: 1-466.

DOLLFUS R.P. 1969: De quelques cestodes tétrarhynques (hétéracanthes et pécilacanthes) recoltés chez des poissons de la Meditérranée. Vie Milieu, sér. A, 20: 491-542.

GARMAN S. 1913: The plagiostoma. Mem. Mus. Comp. Zool. 36: 1-515.

LAURIE J.S. 1961: Carbohydrate absorption in cestodes from elasmobranch fishes. Comp. Biochem. Physiol. 4: 63-71.

McVICAR A.H. 1979: The distribution of cestodes within the spiral intestine of Raja naevus Müller and Henle. Int. J. Parasitol. 9: 165-176.

PALM H. 1995: Untersuchungen zur Systematik von Rüsselbandwürmern (Cestoda: Trypanorhyncha) aus atlantischen Fischen. Berichte aus dem Institut für Meereskunde an der Christian Albrechts Universität, Kiel, 275: 1-238. 
READ C.P. 1957: The role of carbohydrates in the biology of tapeworms. III. Studies on two species from dogfish. Exp. Parasitol. 6: 288-293.

SAKANARI J. 1989: Grillotia heroniensis, sp. nov., and G. overstreeti, sp. nov., (Cestoda: Trypanorhyncha) from Great Barrier Reef fishes. Aust. J. Zool. 37: 81-87.

SCHOLZ T., GARIPPA G., SCALA A. 1993: Grillotia epinepheli sp. n. (Cestoda: Trypanorhyncha) plerocerci from the teleost, Epinephelus guaza, in Sardinia, Italy. Folia Parasitol. 40: 23-28.

WILLIAMS A.D. 1982: Cestode faunal ecology in elasmobranch fishes. M. Sc. Thesis. University of MassachusettsDartmouth, North Dartmouth, Massachusetts, USA, 134 pp.

WILLIAMS H.H. 1960: The intestine in members of the genus Raja and host-specificity in the Tetraphyllidea. Nature 188: 514-516.
WILLIAMS H.H. 1966: The ecology, functional morphology and taxonomy of Echeneibothrium Beneden, 1849 (Cestoda: Tetraphyllidea), a revision of the genus and comments on Discobothrium Beneden, 1870, Pseudanthobothrium Baer, 1956, and Phormobothrium Alexander, 1963. Parasitology 56: 227-285.

WILLIAMS H.H. 1968: Phyllobothrium piriei sp. nov. (Cestoda: Tetraphyllidea) from Raja naevus with a comment on its habitat and mode of attachment. Parasitology 58: 929-937.

WILLIAMS H.H., McVICAR A.H., RALPH R. 1970: The alimentary canal of fish as an environment for helminth parasites. Symp. Brit. Soc. Parasitol. 8: 43-77. 